\title{
Teaching Research on Higher Vocational Pre-School Education of Professional Art Course Based on Innovation and Entrepreneurship Education
}

\author{
Yan Yang \\ Qingdao Vocational and Technical College, Qingdao, China \\ Email: mlbsabc@sina.com
}

How to cite this paper: Yang, Y. (2018). Teaching Research on Higher Vocational Pre-School Education of Professional Art Course Based on Innovation and Entrepreneurship Education. Creative Education, 9, 713-718.

https://doi.org/10.4236/ce.2018.95053

Received: March 13, 2018

Accepted: April 20, 2018

Published: April 23, 2018

Copyright $\odot 2018$ by author and Scientific Research Publishing Inc. This work is licensed under the Creative Commons Attribution International License (CC BY 4.0).

http://creativecommons.org/licenses/by/4.0/

\section{(c) (i) Open Access}

\begin{abstract}
Pre-school education is the core content of education teaching system, and art is an indispensable professional course. Higher vocational art teachers not only need to pay attention to the improvement of students' main professional abilities, but also should pay attention to the improvement of students' aesthetic consciousness and personal cultivations in modern innovation and entrepreneurship education perspective. Aimed at cultivating talents with high-quality, innovation and entrepreneurship, we should optimize the curriculum, teaching content and teaching methods of art courses in order to further improve the teaching quality of education professional art courses lay a foundation. In recent years, the ministry of education has carried out some programs to cultivate college students' innovation and entrepreneurship. Art is an important course to improve students' aesthetic consciousness and personal cultivations. At present, many higher vocational preschool education institutions have included professional art course as one of the compulsory courses, but there are still many problems in preschool education. This paper puts forward some measures to promote higher vocational college students' innovation and entrepreneurship development.
\end{abstract}

\section{Keywords}

Innovation and Entrepreneurship, Higher Vocational Pre-School Education, Professional Art, Early Childhood Educator

\section{Introduction}

Along with the improvement of national material living conditions and many negative news reports related to children, there is a growing demand for early 
childhood educator from all walks of life. At the same time, the state organs also made explicit proposals in the national medium and long-term plan for the reform and development of education (2010-2020) that early childhood educator should develop children's intelligence under the premise of ensuring the healthy growth of children, and guide them to develop good living habits, starting with the development of "children's body and mind" in the process of teaching work. Higher vocational pre-school education is the main position for preschool teachers. Higher vocational pre-school education should improve the training requirements of preschool teachers according to the contents of national documents actively in order to develop more professional children education practitioners.

The cultivation of students' innovation and entrepreneurship ability is the latest demand of the party and the state in accordance with the current situation of employment development of university students and the development trend of market macro-economy. In recent years, the ministry of education has put forward long-term development projects such as "innovation pilot zone for college students' talent cultivation model" and "training for college students' innovation and entrepreneurship program", hoping to export more talents to the market. Today, under the guidance of innovation and entrepreneurship development, many engineering disciplines focus on the development goal of "cultivating innovative entrepreneurial talents" and make adjustments to the course and teaching methods of subjects, which has effectively improved the teaching quality of the subjects. Pre-school education is a basic subject of which the main development goal is to train preschool teachers. The cultivation of individual professional ability and cultural accomplishment during the study period has many influences on the development of national basic education and the development of children's healthy personality. To this end, this article takes the subject of art course as the main content to further consolidate the position of professional art course teaching in pre-school education in order to cater to the national "innovation and entrepreneurship talents" training development goals. The teaching system of higher vocational art is optimized from three aspects: professional curriculum setting, teaching content and teaching method, with the aim to contribute to the improvement of the teaching quality of education professional art course.

\section{The Value of Professional Art Course Teaching in Higher Vocational art Education}

Professional art course is the core content of higher vocational college education of comprehensive art teaching activity. Facing the country's latest requirements for preschool teachers, the value of preschool professional art course teaching in higher vocational colleges is becoming more and more obvious, especially in two aspects. First, it is conducive to the cultivation of children educators' affinity and personal charms. As a preschool teacher, affinity and personal charm are the 
foundations for their good relationship with children which have decisive influence on the development of preschool teachers' teaching activities. This requires them to hone their patience through professional courses during their study in higher vocational colleges, enhance personal affinity and personal charm in order to lay the foundation for children education in the future.

The art discipline is conducive to the cultivation of students' abilities. During the professional study period, higher vocational preschool professional art teachers will bring students' created art paintings. The long creative process can effectively improve students' basic drawing ability, and also enable the early childhood educator to learn to use art to express their inner feelings, thus enhance the affinity and personal charm of education. Second, it is conducive to the development of children educators' art appreciation ability and cultural improvement. Children education teaching activities are designed to foster good habits of children, and cultivate children's healthy, optimistic and positive characteristics. This requires children education practitioners themselves to have high cultural literacy and good life behaviors. For this reason, teachers of pre-school education should actively use classroom teaching to enhance their cultural literacy when they are studying in colleges.

As an art subject with thousands of years of cultural history, domestic excellent art works are numerous. The appreciation of excellent works enables the viewers to feel the beauty of art in the works, and let them understand the development history of our long culture through art works. At the present stage, many higher vocational preschool education institutions have included professional art course as one of the compulsory courses in the call of national policy, which determined the status of professional art courses in pre-school education (Tai, 2015).

\section{The Optimization of Pre-School Professional art Curriculum under the Perspective of Innovation and Entrepreneurship Development}

The development value of professional art curriculum teaching is increasingly reflected. To promote education development of the whole country and solve the problem of difficult employment of fresh graduates, in May 2015, the state council issued the implementation opinions on deepening the education reform of innovation and entrepreneurship in institutions of higher schools according to the relevant content of innovation-driven development strategy. The document brings the development of "innovation and entrepreneurship education" to a new height, and it also brings many inspirations to the optimization of higher vocational pre-school education of professional art course, which are reflected in the following two aspects.

\subsection{To Clarify the Teaching Objective of the Professional Art Course for Preschool Professional}

The so-called "innovation and entrepreneurship education" is an education 
training concept which cultivates students' innovative spirit, entrepreneurial awareness and ability. Based on the current employment status of fresh graduates, the development concept is a breakthrough of innovation teaching idea. In modern social environment, innovation refers to a life attitude that dares to try and break through. Entrepreneurship means developing new industries or positions to contribute to social development based on social economy, politics and culture in the context of a modern society.

Practice shows that people with an innovative spirit are more likely to seize opportunities in a market environment under the increasingly fierce commercial competition environment. Thus, innovation is the foundation of entrepreneurship development. In understanding "innovation and entrepreneurship education" we should think of it as a whole. It should be regarded as a new teaching idea that emphasizes the integration of professional and practice teaching (Zhao, 2016).

For higher vocational preschool professional art teaching, higher vocational colleges gradually realized the value and status of professional art course teaching in pre-school education. However, many vocational colleges have not defined the teaching objectives of art courses. As a result, it is difficult to improve the teaching quality of professional art courses. And the emergence of innovation and entrepreneurship teaching concept has provided the direction for the construction of the teaching goal of the preschool fine arts (Yao, 2017).

\subsection{To Enrich the Content and Teaching Methods of Preschool Art Courses}

From the perspective of innovation and entrepreneurship education development concept, the proposal of education innovation and entrepreneurship is based on solving the problem of domestic fresh employment.

It emphasizes is on coexist of professional education and practical education. This requires the teachers of higher vocational preschool professional art courses to optimize the teaching content of professional art courses in order to improve the teaching quality of fine arts and achieve the latest development goals.

In professional courses, besides the basic course of art painting, high vocational preschool arts teachers should also have more theoretical and artistic evaluation courses, such as art history course, fine arts theory course and art works appreciation course. On the one hand, it can help students broaden their horizons. On the other hand, the creation of art appreciation courses can also help students to expand their thinking ways, exercising the future teaching practitioner's independent thinking ability (Liu et al., 2014).

In practice course setting, the teaching goal of preschool fine arts courses in higher vocational colleges is to export more high-quality and highly skilled children education practitioners. To this end, professional art teachers in higher vocational colleges should have more practice chances in addition to the training courses of art and painting. For example, students will be offered courses on 
their own, leting future education practitioners teach other students about painting skills in the course. On the one hand, students can consolidate their knowledge in the process of explanation. On the other hand, it can also help teachers to understand the learning situation of students' professional courses, and timely adjust the course content according to the students' shortage.

When enriching the content of the teaching, teachers should also cater to the trend of the times and students' psychological characteristics to make adjustments to the teaching methods and apply modern new media equipment and interactive teaching methods into classroom teaching. In the campus environment, teachers can also regard the class as a unit, encourage and organize students to hold art exhibitions in order to exercise students' organizational ability and practical ability. It meets the requirements of innovation and entrepreneurship education teaching philosophy and also enables students to feel the joy of paintings (Yang, 2015).

\section{The Prospect on Development of Higher Vocational Preschool Art Course from the Perspective of Innovation and Entrepreneurship}

In terms of the current development of preschool education, there are still many problems in education. It is especially reflected in the professional technical competence and cultural literacy of preschool educators. The frequent occurrence of negative news reports in kindergarten teaching in 2017 has brought the development of preschool education to the forefront. For example, the news on child abuse incidents in C-trip kindergartens aroused public concerns on pre-school education. Professional art course teaching is the key content of education. It is also the main course for the training of higher vocational pre-school education practitioners in education. The quality of professional art course teaching is not only related to the future employment of students in vocational colleges, but also is related to the development of education of the next generation of the country. This requires the professional art education teachers comprehensively digest and absorpt innovation and entrepreneurship teaching concept and further improve the teaching quality of education when carrying out the teaching activities (Wang, 2016).

\section{Conclusion}

As described above, pre-school education is an important part of education teaching system, and art is an indispensable professional course. Art course is conducive to the cultivation of children educators' affinity and personal charms, and to the development of children educators' art appreciation ability and cultural improvement. This paper puts forward two ways to optimize the pre-school professional art curriculum under the perspective of innovation and entrepreneurship development. But higher vocational schools and teachers should think out more ways to optimize the art curriculum. 


\section{References}

Liu, Y., Yan, G. D., Meng, W., Quan, Y. T., Lu, J. H., Teng, L. R., \& Meng, Q. F. (2014). Innovation and Entrepreneurship Education Is Deeply Integrated with Education. China University Teaching, 11, 35-37.

Tai, K. F. (2015). The Present Situation and Coping Strategies of Pre-School Education Professional Art Curriculum Decision-Making. Chinese Vocational and Technical Education, 26, 81-85, 93.

Wang, Z. R. (2016). Research on the Characteristics and Development Orientation of Education in Chinese Universities Innovation and Entrepreneurship. Educational Research, 37, 56-63.

Yang, X. H. (2015). Research on Education and Innovative Talent Cultivation in Universities in China. China Higher Education Research, 1, 39-44.

Yao, R. (2017). The Importance of Fine Arts Courses in Pre-School Education. Art Education Research, 19, 158-159.

Zhao, J. X. (2016). It Is Imperative to Reform the Higher Vocational Professional Art Teaching of Education. Modern Communication, 11, 168-170. 